\title{
In Focus
Spotlight on the April 16 Issue
}

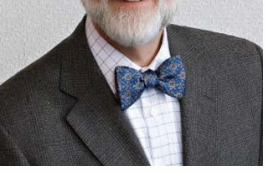

\author{
Robert A. Gross, MD, PhD, FAAN \\ Editor-in-Chief, Neurology ${ }^{\circledR}$
}

\section{Headache as a risk factor for neurovascular events in pediatric brain tumor patients}

In this retrospective analysis of 265 patients followed for 6 years, severe recurrent headache increased the risk of stroke or TIA by nearly 5-fold. More vigilant monitoring and vascular imaging may be warranted in this subgroup along with future studies of antiplatelet therapy or other attempts to reduce stroke risk.

See p. 1452

From editorialists Heyer \& Mack: "As more children with brain tumors survive into adulthood, efforts at keeping them healthy and maintaining a high quality of life cannot be overemphasized."

See p. 1448

Interarm blood pressure difference and mortality in patients with acute ischemic stroke

The authors examined 834 patients for the prognostic value of interarm difference of blood pressure. Large systolic and diastolic interarm differences in stroke patients were associated with an increased risk of mortality. Blood pressures should be measured in both arms routinely to identify highrisk patients in order to diagnose and treat hypertension properly.

See p. 1457

The 5- $\mathrm{HT}_{1 \mathrm{~A}}$ receptor and 5-HT transporter in temporal lobe epilepsy

In patients with both temporal lobe epilepsy (TLE) and depression, compared to TLE alone, PET scans showed reduced serotonin transporter activity and increased serotonin synaptic availability, suggesting a compensatory mechanism for serotonin receptor loss. Selective serotonin reuptake inhibitors are appropriate treatment for depression in epilepsy. See p. 1465; Editorial, p. 1450

\section{Gray matter atrophy distinguishes between Parkinson disease motor subtypes}

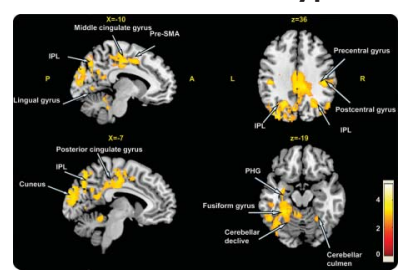

Among patients with Parkinson disease (PD), the postural instability gait difficulty subtype is related to basal ganglia disturbances but also involves cortical gray matter atrophy, as demonstrated using voxel-based morphometry analysis. This atrophy is associated with lower functional connectivity with subcortical regions. Cortical degeneration apparently contributes to a common motor subtype of PD.

See p. 1476

\section{Autosomal dominant vasovagal syncope: Clinical features and linkage to chromosome $15 \mathrm{q} 26$}

Vasovagal syncope (VVS) affects a quarter of the population and is frequently encountered in neurologic practice. The authors describe 6 families with autosomal dominant VVS and establish linkage to chromosome 15q26 in the largest family. Although VVS usually follows complex inheritance, their findings indicate that autosomal dominant inheritance is not rare.

See p. 1485

Human herpes 6 virus encephalitis complicating allogeneic hematopoietic stem cell transplantation :

In 243 patients undergoing hematopoietic stem cell transplantation, 9 patients with human herpes 6 virus encephalitis were identified. Only 3 had typical clinical and radiologic findings of limbic encephalitis without any correlation to the viral load in the CSF. The spectrum of clinical presentation extends beyond the findings of limbic encephalitis and is associated with higher mortality.

See p. 1494

Cognitive impairment differs between primary progressive and relapsing-remitting MS

Cognitive impairment is underestimated in primary progressive MS (PPMS). This study compared cognitive impairment in 41 patients with PPMS, 60 patients with relapsing-remitting MS (RRMS), and 415 controls. Cognitive impairment was more frequent and severe in patients with PPMS than RRMS, affecting a wide range of cognitive domains. See p. 1501

Timed 25-Foot Walk: Direct evidence that improving $20 \%$ or greater is clinically meaningful in MS

Using the patient-reported MS Walking Scale-12, multiple measurements, and profiles, $\geq 20 \%$ Timed 25-Foot Walk (T25FW) improvements were associated with clinically meaningful changes in self-reported walking ability. More support for T25FW's utility is warranted, but don't be misled: walking measurement is shown to be complex, diverse, and challenging See p. 1509

NB: "Comprehensive Review in Clinical Neurology: A Multiple Choice Question Book for the Wards and Boards, First Edition," see p. e175. To check out other Resident \& Fellow Media and Book Reviews, point your browser to www.neurology.org and click on the link to the Residents \& Fellows Section. 


\section{Neurology}

Spotlight on the April 16 Issue

Robert A. Gross

Neurology 2013;80;1447

DOI 10.1212/WNL.0b013e31828e5047

This information is current as of April 15, 2013

\section{Updated Information \&} Services

Permissions \& Licensing

Reprints including high resolution figures, can be found at: http://n.neurology.org/content/80/16/1447.full

Information about reproducing this article in parts (figures,tables) or in its entirety can be found online at:

http://www.neurology.org/about/about_the_journal\#permissions

Information about ordering reprints can be found online:

http://n.neurology.org/subscribers/advertise

Neurology ${ }^{\circledR}$ is the official journal of the American Academy of Neurology. Published continuously since 1951, it is now a weekly with 48 issues per year. Copyright @ 2013 American Academy of Neurology. All rights reserved. Print ISSN: 0028-3878. Online ISSN: 1526-632X.

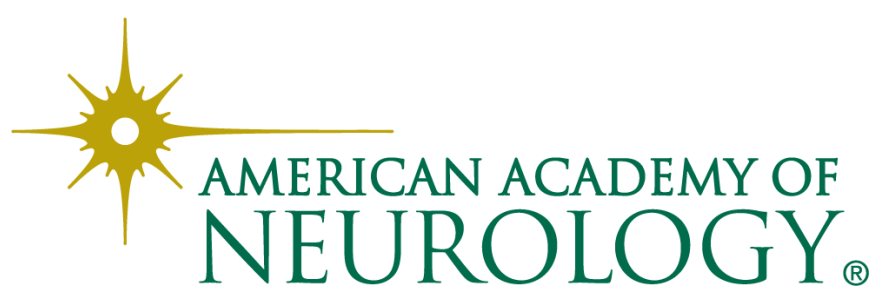

